\title{
Factors contributing to delay in parasite clearance in uncomplicated falciparum malaria in children
}

\author{
Akintunde Sowunmi ${ }^{1,2^{*}}$, Elsie O Adewoye ${ }^{3}$, Grace O Gbotsho ${ }^{1,2}$, Christian T Happi ${ }^{2}$, Abayomi Sijuade ${ }^{1}$, \\ Onikepe A Folarin', Titilope M Okuboyejo ${ }^{1}$, Obaro S Michael ${ }^{1,2}$
}

\begin{abstract}
Background: Drug resistance in Plasmodium falciparum is common in many endemic and other settings but there is no clear recommendation on when to change therapy when there is delay in parasite clearance after initiation of therapy in African children.
\end{abstract}

Methods: The factors contributing to delay in parasite clearance, defined as a clearance time $>2 \mathrm{~d}$, in falciparum malaria were characterized in 2,752 prospectively studied children treated with anti-malarial drugs between 1996 and 2008.

Results: 1,237 of 2,752 children (45\%) had delay in parasite clearance. Overall 211 children (17\%) with delay in clearance subsequently failed therapy and they constituted 72\% of those who had drug failure, i.e., 211 of 291 children. The following were independent risk factors for delay in parasite clearance at enrolment: age less than or equal to 2 years (Adjusted odds ratio $[A O R]=2.13,95 \%$ confidence interval $[\mathrm{Cl}] 1.44-3.15$, $\mathrm{P}<0.0001$ ), presence of fever $(A O R=1.33,95 \% C l=1.04-1.69, P=0.019)$, parasitaemia $>50,000 / \mathrm{ul}(A O R=2.21,95 \% \mathrm{Cl}=1.77-2.75$, $\mathrm{P}<0.0001)$, and enrolment before year $2000(\mathrm{AOR}=1.55,95 \% \mathrm{Cl}=1.22-1.96, \mathrm{P}<0.0001)$. Following treatment, a body temperature $\geq 38^{\circ} \mathrm{C}$ and parasitaemia $>20000 / \mu$ a day after treatment began, were independent risk factors for delay in clearance. Non-artemisinin monotherapies were associated with delay in clearance and treatment failures, and in those treated with chloroquine or amodiaquine, with pfmdr 1/pfcrt mutants. Delay in clearance significantly increased gametocyte carriage $(P<0.0001)$.

Conclusion: Delay in parasite clearance is multifactorial, is related to drug resistance and treatment failure in uncomplicated malaria and has implications for malaria control efforts in sub-Saharan Africa.

\section{Background}

The emergence and spread of multidrug resistance in Plasmodium falciparum is a major obstacle to successful chemotherapeutic control of the disease. Resistance to chloroquine (CQ) and sulphadoxine-pyrimethamine (SP) is now widespread in sub-Saharan Africa, South Asia and South America [1,2] and there is an increased chance that resistance to mefloquine (MQ), already widespread in Southeast Asia [3-6], may spread to Africa. With increasing failure of amodiaquine (AQ) in areas of intense transmission [7-9] and increasing

\footnotetext{
* Correspondence: akinsowunmi@hotmail.com

'Department of Pharmacology \& Therapeutics, University of Ibadan, Ibadan, Nigeria
}

\section{() Biomed Central}

(c) 2010 Sowunmi et al; licensee BioMed Central Ltd. This is an Open Access article distributed under the terms of the Creative Commons Attribution License (http://creativecommons.org/licenses/by/2.0), which permits unrestricted use, distribution, and reproduction in any medium, provided the original work is properly cited.

selection of $P$. falciparum multidrug resistance gene 1 $(P f m d r 1)$ in asexual and sexual parasites following treatment of infections with artemether-lumefantrine (AL) [10], there is a rising spectre of reduced responses to artemisinin-based combination therapy (ACT) in Africa.

Despite increasing drug treatment failure, there is no clear guidelines, at least in Nigeria, about the time to change anti-malarial drug treatment if parasites do not clear quickly from peripheral blood following treatment of uncomplicated acute infections in African children. It is postulated in the present study that, parasite clearance exceeding two days is associated with risk of treatment failure and resistance and could be used as a criterion to change therapy in very young children. The present 
study reports the relationship between delay in parasite clearance and anti-malarial treatment failure in children with falciparum malaria in an area of intense transmission in south-western Nigeria, where resistance in P. falciparum to CQ and SP deteriorated steadily over the past ten years.

\section{Methods}

\section{Patients}

The studies took place between July 1996 and July 2008 in patients presenting at the University College Hospital in Ibadan, a hyperendemic area for malaria in southwestern Nigeria [11]. Ethical clearance was provided by the local ethics committee. During the period, a series of anti-malarial drug studies were conducted to evaluate the efficacy and safety of different treatment regimens (Table 1). Details of the drug efficacy studies have been described before [12-16].

Briefly, children with symptoms compatible with acute falciparum malaria who fulfilled the following criteria were enlisted in the study: age 144 months or below, mono-infection with $P$. falciparum, parasitaemia $\geq 2,000$ asexual forms/ $\mu \mathrm{l}$ blood, negative urine tests for antimalarial drugs 4-aminoquinolines and sulphonamides
(Dill-Glazko and lignin tests, respectively), absence of concomitant illness, no evidence of severe malaria [17], and written informed consent given by parents or guardians. After enrolment and start of treatment (day 0), follow-up with clinical and parasitological evaluation was at days 1-7, and then on days $14-28$ up to 2004 . After 2004, follow-up was for $42 \mathrm{~d}$. Clinical evaluation consisted of a general clinical examination including measurement of weight, core temperature and physical examination.

\section{Assessment of parasitaemia}

Thick and thin blood films prepared from a finger prick were Giemsa-stained and were examined by light microscopy under an oil-immersion objective, at $\times 1,000$ magnification, by two independent assessors. Parasitaemia in thick films was estimated by counting asexual parasites relative to 1,000 leukocytes, or 500 asexual forms, whichever occurred first. From this figure, the parasite density was calculated assuming a leukocyte count of $6,000 / \mu \mathrm{l}$ of blood. Gametocytes were also counted in thick blood films against 1,000 leukocytes assuming an average leukocyte count of $6,000 / \mu \mathrm{l}$ of blood [18-20]. Haematocrit was done at enrolment in 994 of the

Table 1 Treatment regimens and time of study in the children enrolled

\begin{tabular}{|c|c|c|c|}
\hline Drugs* & Regimenst & No of patients & Year \\
\hline $\mathrm{AQ}$ & $30 \mathrm{mg} / \mathrm{kg}$ of amodiaquine base over 3 days, that is, $10 \mathrm{mg} / \mathrm{kg}$ daily & 573 & 2000-2006 \\
\hline AQAS & Artesunate given as $4 \mathrm{mg} / \mathrm{kg}$ dail for $3 \mathrm{~d}$ plus amodiaquine given as in $\mathrm{AQ}$ above & 142 & 2004-2005 \\
\hline AQPS & $\begin{array}{l}\text { Amodiaquine given as in AQ above plus sulphadoxine-pyrimethamine given as } 25 \mathrm{mg} / \mathrm{kg} \\
\text { of the sulphadoxine component at presentation }\end{array}$ & 69 & 2000 \\
\hline AQSP & $\begin{array}{l}\text { Amodiaquine given as in AQ above plus sulphalene-pyrimethamine given as } 25 \text { mg/kg } \\
\text { of the sulphalene component at presentation }\end{array}$ & 91 & 2006 \\
\hline AMQ & Mefloquine given as $25 \mathrm{mg} / \mathrm{kg}$ at presentation plus artesunate as given in AQAS above & 174 & $2007-2008$ \\
\hline $\mathrm{AL}$ & $\begin{array}{l}\text { Artemether }(20 \mathrm{mg}) \text { plus lumefantrine }(120 \mathrm{mg}) \text { given thus: } 5-14 \mathrm{~kg} \text { received } 1 \mathrm{tab} ., \\
15-24 \mathrm{~kg} \text { received } 2 \text { tab., } 25-34 \mathrm{~kg} \text { received } 3 \text { tab., }>34 \mathrm{~kg} \text { received } 4 \text { tab. } \\
\text { at presentation, } 8 \mathrm{~h} \text { later and at 24, 36, } 48 \text { and } 60 \mathrm{~h} \text { after first dose }\end{array}$ & 90 & 2006 \\
\hline AS & Artesunate given as 28 mg/kg over 7 days, that is, 4 mg/kg daily & 120 & 2006 \\
\hline COT & Co-trimoxazole given as 20 mg of the sulphamethoxazole component twice daily & 104 & 1998-1999 \\
\hline CQ & $30 \mathrm{mg} / \mathrm{kg}$ of chloroquine base over 3 days, that is, $10 \mathrm{mg} / \mathrm{kg}$ daily & 388 & $1996-2004$ \\
\hline CQCP & $\begin{array}{l}30 \mathrm{mg} / \mathrm{kg} \text { of chloroquine base over } 3 \text { days, that is, } 10 \mathrm{mg} / \mathrm{kg} \text { daily plus chlorpheniramine } 8 \mathrm{mg} \\
\text { start and } 4 \mathrm{mg} 8 \text { hourly for } 5 \mathrm{~d} \text {. }\end{array}$ & 315 & 1996-1999 \\
\hline CQKET & $\begin{array}{l}30 \mathrm{mg} / \mathrm{kg} \text { of CQ base over } 3 \text { days, i.e., } 10 \mathrm{mg} / \mathrm{kg} \text { daily plus ketotifen } 25 \text { mg/kg statim, } \\
\text { followed by } 0.125 \mathrm{mg} / \mathrm{kg} 8 \text { hourly for } 4 \mathrm{~d} \text {. }\end{array}$ & 70 & 2001 \\
\hline CQPS & $\begin{array}{l}30 \mathrm{mg} / \mathrm{kg} \text { of amodiaquine base over } 3 \text { days, that is, } 10 \mathrm{mg} / \mathrm{kg} \text { daily plus sulphadoxine-pyrimethamine } \\
\text { given as } 25 \mathrm{mg} / \mathrm{kg} \text { of the sulphadoxine component at presentation }\end{array}$ & 107 & $2000 / 2004$ \\
\hline MQ & Mefloquine given as 25 mg/kg at presentation & 176 & $2007-2008$ \\
\hline SP & Pyrimethamine-sulphadoxine given as 25 mg/kg of the sulphadoxine component at presentation & 291 & $1996-2004$ \\
\hline SPP & $\begin{array}{l}\text { Sulphadoxine-pyrimethamine given as in PS above plus probenecid at } 20-25 \mathrm{mg} / \mathrm{kg} \text { in two divided } \\
\text { doses daily for } 3 \text { day }\end{array}$ & 42 & 2004 \\
\hline
\end{tabular}

† All drugs were administered orally. AQ, amodiaquine; AQART, amodiaquine plus artesunate; AQPS, amodiaquine plus pyrimethamine-sulphadoxine; AQSP, amodiaquine-sulphalene-pyrimethamine; ARTMF, mefloquine plus artesunate; ARTMLUM, artemether plus lumefantrine; AS, artesunate; COT, cotrimoxazole; CQ, chloroquine; CQCP, chloroquine plus chlorpheniramine; CQKET, chloroquine plus ketotifine; CQPS, chloroquine plus pyrimethamine-sulphadoxine; MQ, mefloquine; PS, pyrimethamine-sulphadoxine; PSP, pyrimethamine-sulphadoxine plus probenecid; 
patients treated with non-artemisinin combination therapy (NACT) or ACT in order to evaluate the safety of combination anti-malarial therapies.

\section{Evaluation of response to drug treatment}

Response to drug treatment was assessed using World Health Organization (WHO) criteria [21] as follows: $\mathrm{S}=$ sensitive, clearance of parasitaemia without recurrence; RI (mild resistance) = parasitaemia disappears but reappears within 7 to 14 days; RII (moderate resistance) = decrease of parasitaemia but no complete clearance from peripheral blood; RIII (severe resistance) = no pronounced decrease or increase in parasitaemia at 48 hours after treatment. In those with sensitive or RI response, parasite clearance time (PCT) was defined as the time elapsing from drug administration until there was no patent parasitaemia for at least $72 \mathrm{~h}$. Delay in parasite clearance was defined as a parasite clearance time $>2 \mathrm{~d}$, and was based on the asexual life cycle of 48 $h$ in the infected erythrocyte [22]. The above criteria used for assessing responses to anti-malarials were used in order to maintain uniformity and because they were the recommended criteria when studies started.

\section{Molecular analysis of pfmdr 1 and pfcrt}

At enrolment, $100 \mu \mathrm{l}$ of capillary blood was collected on to $3 \mathrm{MM}$ Whatman ${ }^{\mathrm{TM}}$ filter paper for resistance markers determination in 2000 and 2006 in those treated with CQ or AQ. Pfmdr 1 and pfcrt genotypes were assessed by PCR using methods described previously $[7,10]$. Single nucleotide polymorphisms in pfmdr 1 and pfcrt were detected by nested PCR-RFLP methods.

\section{Statistical analysis}

Data were analysed using version 6 of the Epi-Info software [23], and the statistical program SPSS for Windows version 10.01 [24]. Proportions were compared by calculating $\chi^{2}$ with Yates' correction. Normally distributed, continuous data were compared by Student's t-tests and analysis of variance (ANOVA). Data not conforming to a normal distribution were compared by the MannWhitney U-test and the Kruskal-Wallis test (or by Wilcoxon rank sum test). A multiple logistic regression model was used to test the association between parasite clearance $>2 \mathrm{~d}$ (yes or no at presentation or during follow up) and factors that were significant at univariate analysis: age, presence of fever, asexual parasitaemia at presentation or during follow-up, a history of vomiting, and drug treatment. Because the study was conducted over a period of 12 years, time in years since the commencement of trials was included as a covariate in the model for pretreatment delay in parasite clearance. Pvalues of $<0.05$ were taken to indicate significant differences.

\section{Results}

Between July 1996 and July 2008, 2,752 children (1342 females) were enrolled into the drug studies. All were recruited into prospective randomized studies and all had primary infections with $P$. falciparum. There were 1,716 under five-year olds. The geometric mean parasitaemia at enrolment was $34,044 / \mu \mathrm{l}(95 \%$ CI $30,400-33,664)$ (Table 2). Follow up was achieved in 2,562 children for up to 21 days and in 2,122 children for 28 or 42 days.

\section{Treatment failures}

Overall 57 of the 2,752 children $(2.1 \%)$ had treatment failure by day 7 , and this rose to $113 / 2,695(4.2 \%)$ by day 14 , and $62 / 796(7.8 \%)$ by day $21\left(\chi^{2}\right.$ for trend = 155.8, $\mathrm{P}<0.0001)$.

\section{Drug treatment and delay in parasite clearance}

Overall, delay in parasite clearance occurred in 1237 of the 2752 children (45\%) (Figure 1). The highest proportions of children showing delay in parasite clearance were found in those treated with CQ (70.8\%), PS (63.9\%), CQCP (60\%), COT (58.6\%) AQ (52\%) CQKET (51.4\%) CQPS (42\%), AQPS (37.6\%), AQSP (37.3\%), PSP (30.9\%), and MQ (22.7\%). The proportions of children with delay in parasite clearance were significantly lower in those treated with AS (2.5\%), AQAS (9.9\%), AL (6.6\%) and, AMQ (5.7\%) when compared with the latter group above $\left(\chi^{2}=447.91, \mathrm{P}<0.0001\right)$. There was no significant difference in the proportions of children with delay in clearance in those treated with AS (3 of 120), AQAS (14 of 142), AL (6 of 90), and AMQ (10 of 174)

Table 2 Baseline clinical and parasitological parameters of the $\mathbf{2 7 5 2}$ children enrolled in the study

\begin{tabular}{lll}
\hline Variables & $\begin{array}{l}\text { Mean } \pm \text { SD } \\
\text { (range) }\end{array}$ & 95\% Cl \\
\hline Age (year) & $6.1 \pm 3.0(0.5-12)$ & $6.0-6.2$ \\
$\quad$ No. $<5$ years & $1716(63 \%)$ & \\
Weight $(\mathrm{kg})$ & $17.3 \pm 6.4(5-47)$ & $17.0-17.6$ \\
Axillary temperature $\left({ }^{\circ} \mathrm{C}\right)(\mathrm{n}=2428)$ & $38.3 \pm 1.2(34-42)$ & $38.2-38.3$ \\
$\quad$ No. with $>40^{\circ} \mathrm{C}$ & 210 & \\
Haematocrit $(\%)(\mathrm{n}=994)$ & $30.5 \pm 4.8(10-51)$ & $30.1-30.7$ \\
$\quad$ No. with $<30 \%$ & 380 & \\
Parasitaemia $(/ \mu \mathrm{l})$ & & \\
$\quad \mathrm{GM}$ & 34,044 & \\
$\quad$ Range & $2009-1,194,285$ & \\
$\quad$ No with $>100,000(/ \mu l)$ & $638(23.2 \%)$ & $2.9-3.0$ \\
$\quad$ No. with $>250,000(/ \mu \mathrm{l})$ & $187(6.8 \%)$ & $1.2-1.3$ \\
Gametocytaemia $(/ \mu \mathrm{l}) \mathrm{GM}$ & $27(6-4188)$ & \\
Duration of illness $(\mathrm{d})$ & $3.0 \pm 1.4(1-14)$ & $1.3 \pm 1.4(1-9)$ \\
Duration of vomiting $(\mathrm{d})$ & & \\
\hline
\end{tabular}

$\mathrm{GM}$, geometric mean 
$\left(\chi^{2}=6.1, \mathrm{df}=3, \mathrm{P}=0.10\right)$. The addition of AS to MQ (AMQ) significantly reduced the proportion of patients with delay in clearance ( 40 of 176 for MQ $v 10$ of 174 for AMQ, $\left.\chi^{2}=19.24, P=0.0001\right)$. Similarly, the addition of AS to AQ (AQAS) significantly reduced the proportion of patients with delay in clearance (298 of 573 for AQ $v 14$ of 142 for AQAS, $\left.\chi^{2}=80.49, \mathrm{P}<0.0001\right)$.

\section{Temporal changes in parasite clearance time and} proportion of children with delay in clearance in those treated with chloroquine, sulphadoxine-pyrimethamine and amodiaquine

The changes in parasite clearance times (PCT) and the proportions of children with delay in clearance between
1996 and 2004, or between 2000 and 2006, in patients treated with CQ $(\mathrm{n}=316), \mathrm{SP}(\mathrm{n}=218)$, or AQ $(\mathrm{n}=573)$ were evaluated. There was a significant increase in PCT from $3.08 \pm 1.06 \mathrm{~d}(\mathrm{n}=53)$ in 1996 to $4.23 \pm 2.08 \mathrm{~d}(\mathrm{n}=$ $76)$ in $2004(\mathrm{P}<0.0001)$, but there was no difference in proportion with delay in parasite clearance during the same period $\left(71.7 \%\right.$ in 1996 and $80.2 \%$ in $2004, \chi^{2}$ for trend $=1.36, \mathrm{P}=0.24$ ) in those treated with $\mathrm{CQ}$ (Figure 2).

There was a significant increase in PCT from $3.19 \pm$ $1.72 \mathrm{~d}(\mathrm{n}=48)$ in 1996 to $4.21 \pm 1.84 \mathrm{~d}(\mathrm{n}=71)$ in $2004(\mathrm{P}=0.0001)$ and a significant increase in proportion with delay in parasite clearance during the same period (58.3\% in 1996 and $80.3 \%$ in 2004, $\chi^{2}$ for trend = $5.99, \mathrm{P}=0.014)$ in those treated with SP (Figure 2).

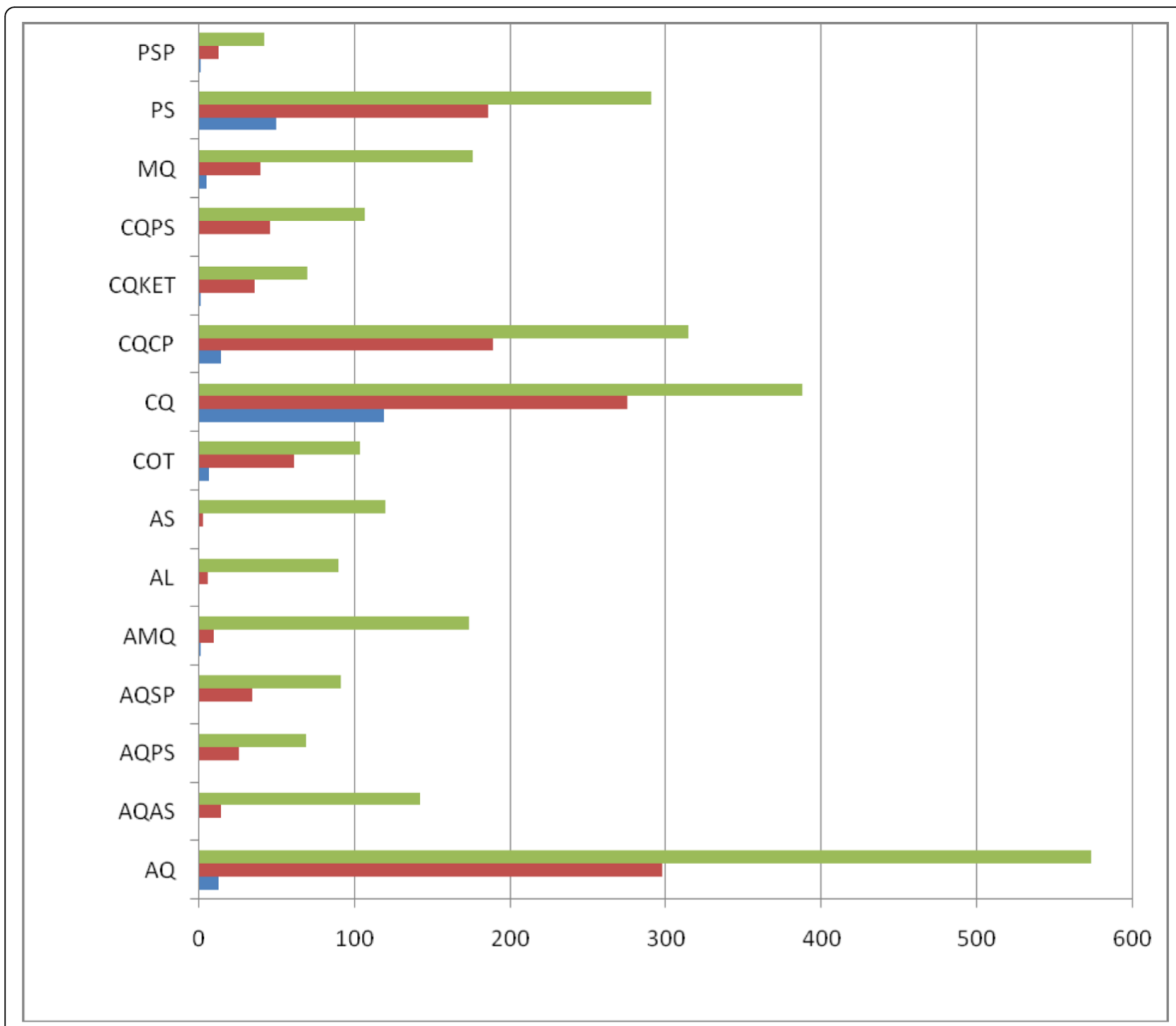

Figure 1 Numbers of children with delay in parasite clearance $(>\mathbf{2} \mathbf{d})$ following treatment with antimalarial drugs. Total enrolled (Green line), No. with parasite clearance $>2 d$ (Red line), No. with parasite clearance $>2 d$ who proceded to failure (Blue line). [see Table 1 for antimalarial drug abbreviations]. 


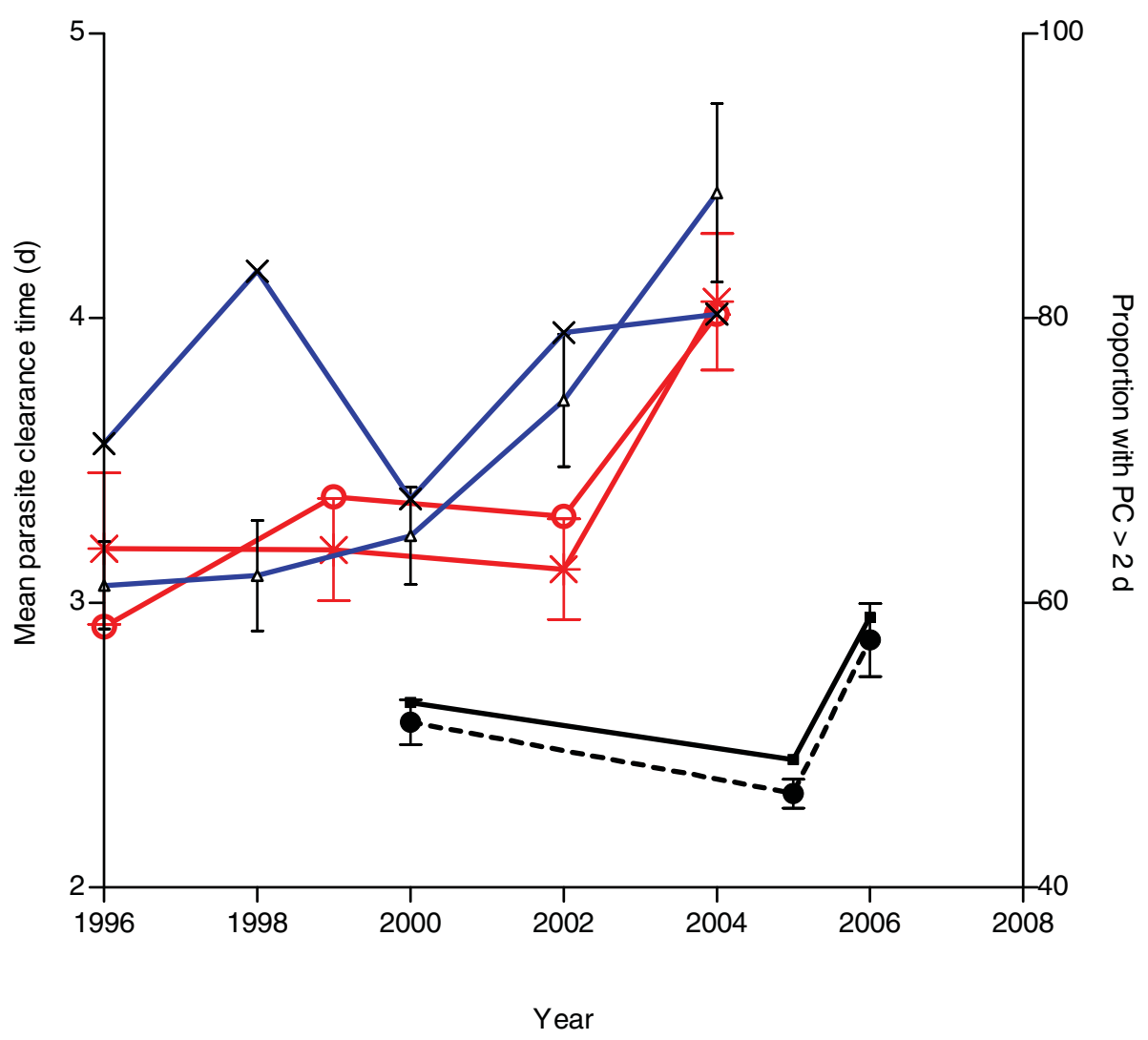

Figure 2 Temporal changes in parasite clearance time (PCT) and proportion with delay in parasite clearance (PC $>2 \mathrm{~d}$ ) in children treated with amodiaquine (AQ), chloroquine (CQ) or pyrimethamine sulphadoxine (PS) between 1996 and 2006. [Proportion of children treated with $A Q$ who had $P C>2 d$ (Black line), Proportion of children treated with $C Q$ who had $P C>2 d(X)$, Proportion of children treated with PS who had PC > $2 \mathrm{~d}(\mathrm{O}), \mathrm{PCT}$ for $\mathrm{AQ}$ treated children (-•-), PCT for CQ treated children (Blue line), PCT for PS treated children (+)]. Bars represent standard deviation.

There was also a significant increase in PCT from 2.58 $\pm 0.80 \mathrm{~d}(\mathrm{n}=104)$ in 2000 to $2.87 \pm 1.39 \mathrm{~d}(\mathrm{n}=118)$ in $2006(\mathrm{P}=0.0001)$, but there was no difference in proportion with delay in parasite clearance during the same period $\left(53 \%\right.$ in 2000 and $59 \%$ in $2006, \chi^{2}$ for trend $=$ $0.81, \mathrm{P}=0.36$ ) in those treated with AQ (Figure 2).

\section{Risk factors for delay in parasite clearance at enrolment}

The following were found to be independent risk factors for delay in parasite clearance at enrolment (Table 3): age $\leq 2$ years (Adjusted odds ratio $[\mathrm{AOR}]=2.13,95 \%$ confidence interval $[\mathrm{CI}]=1.44-3.15, \mathrm{P}<0.0001)$, presence of fever $(\mathrm{AOR}=1.33,95 \% \mathrm{CI}=1.04-1.69, \mathrm{P}=$ $0.019)$, parasitaemia $>50,000 / \mu \mathrm{l}(\mathrm{AOR}=2.21,95 \% \mathrm{CI}=$ 1.77-2.75, $\mathrm{P}<0.0001)$, and enrolment before year 2000 $(\mathrm{AOR}=1.55,95 \% \mathrm{CI}=1.22-1.96, \mathrm{P}<0.0001)$. A history of vomiting was associated with an increased risk of delay in clearance (crude odds ratio $=1.34,95 \% \mathrm{CI}=$ $1.07-1.58, \mathrm{P}=0.009)$.
Risk factors for delay in parasite clearance following initiation of treatment

Following treatment, a body temperature $\geq 38^{\circ} \mathrm{C}$ and parasitaemia $>20,000 / \mu$ l blood a day after treatment began, were independent risk factors for delay in clearance (Table 4). Non-artemisinin monotherapy was associated with delay in clearance.

\section{Delay in parasite clearance and treatment failure}

Of the 20,146,10,15, 19, and 62 children who failed treatment with AQ, CQ, COT, CQCP, MQ, and PS, respectively, $13,119,7,14,5$, and 50 children, respectively were those who previously had delay in parasite clearance (Figure 3). Overall, 291 children failed treatment. Of these, 211 (72\%) had delay in parasite clearance. The latter represent $17 \%$ of the total children (1237) with delay in parasite clearance. Thus delay in clearance may be related to subsequent drug treatment failure. 
Table 3 Predictors of delay in parasite clearance at presentation in children with acute falciparum malaria

\begin{tabular}{|c|c|c|c|c|c|c|}
\hline Variables & Number enrolled & $\begin{array}{l}P C \\
>2 \mathrm{~d}\end{array}$ & $\begin{array}{l}\text { Crude OR } \\
(95 \% \mathrm{Cl}) \\
\end{array}$ & $\begin{array}{l}P \\
\text { Value }\end{array}$ & Adjusted OR $(95 \% \mathrm{Cl})$ & $\begin{array}{l}P \\
\text { Value } \\
\end{array}$ \\
\hline \multicolumn{7}{|l|}{ Age (years) } \\
\hline$>2$ & 2446 & 1076 & 1 & & 1 & \\
\hline$\leq 2$ & 267 & 140 & $1.40(1.09-1.80)$ & 0.008 & $2.13(1.44-3.15)$ & $<0.0001$ \\
\hline \multicolumn{7}{|l|}{ Gender } \\
\hline Female & 1342 & 607 & 1 & & & \\
\hline Male & 1240 & 557 & $0.98(0.84-1.15)$ & 0.870 & - & - \\
\hline \multicolumn{7}{|l|}{ Fever* } \\
\hline Absent & 686 & 252 & 1 & & 1 & \\
\hline Present & 1743 & 842 & $1.6(1.34-1.93)$ & $<0.0001$ & $1.33(1.04-1.69)$ & 0.019 \\
\hline \multicolumn{7}{|c|}{ Duration of illness (d) } \\
\hline$\leq 3$ & 2085 & 926 & 1 & & & \\
\hline$>3$ & 521 & 246 & $1.12(0.90-1.30)$ & 0.225 & - & - \\
\hline \multicolumn{7}{|l|}{ Haematocrit (\%) } \\
\hline$\geq 30$ & 614 & 182 & 1 & & & \\
\hline$<30$ & 380 & 114 & $1.01(0.76-1.34)$ & 0.904 & - & - \\
\hline \multicolumn{7}{|c|}{ 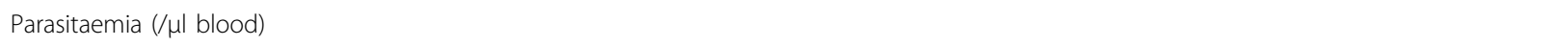 } \\
\hline$\leq 50,000$ & 1607 & 634 & 1 & & 1 & \\
\hline$>50,000$ & 1145 & 603 & $1.70(1.46-1.99)$ & $<0.0001$ & $2.21(1.77-2.75)$ & $<0.0001$ \\
\hline \multicolumn{7}{|l|}{ Gametocytaemia } \\
\hline Absent & 2086 & 896 & 1 & & & \\
\hline Present & 232 & 90 & $0.84(0.63-1.10)$ & 0.224 & - & - \\
\hline \multicolumn{7}{|l|}{ Vomiting } \\
\hline No & 1005 & 519 & 1 & & 1 & \\
\hline Yes & 665 & 387 & $1.34(1.07-1.58)$ & 0.009 & $1.21(0.90-1.51)$ & 0.089 \\
\hline \multicolumn{7}{|l|}{ Hepatomegaly } \\
\hline Absent & 471 & 237 & 1 & & & \\
\hline Present & 798 & 430 & $1.54(0.91-1.44)$ & 0.219 & - & - \\
\hline \multicolumn{7}{|l|}{ Year of enrolment } \\
\hline 2000 onward & 2165 & 872 & 1 & & 1 & \\
\hline Before or 1999 & 587 & 365 & $2.43(2.02-2.94)$ & 0.0 .00 & $1.55(1.22-1.96)$ & $<0.0001$ \\
\hline
\end{tabular}

$\mathrm{Cl}$, confidence interval; OR, odd ratio; $\mathrm{PC}$, parasite clearance, ${ }^{*}$ Body temperature $\geq 37.5^{\circ} \mathrm{C}$

\section{Gametocyte carriage}

Overall $10 \%(282 / 2,752)$ of the children had patent gametocytaemia on presentation. In those treated with CQ gametocyte carriage at enrolment did not increase from $1996(26 \%, 14 / 53)$ to $2003(22 \% 14 / 62), \chi^{2}$ for trend $=0.417, \mathrm{P}=0.23$. Similarly, in those treated with SP, gametocyte carriage at enrolment did not increase from $1996(22 \%, 11 / 48)$ to $2003(20 \% 15 / 72), \chi^{2}$ for trend $=0.075, \mathrm{P}=0.78$. In those treated with $\mathrm{AQ}$ gametocyte carriage at enrolment also did not increase from $2000(11.5 \%, 12 / 104)$ to $2006(13 \% 16 / 120), \chi^{2}$ for trend $=0.55, \mathrm{P}=0.46$.

The majority of children without gametocytaemia at enrolment, who later developed gametocytaemia did so on day $7(36 \%, 156 / 433)$. In those who did not carry gametocyte at enrolment, gametocyte carriage within 
Table 4 Predictors of delay in parasite clearance on day 1 after treatment in children with acute falciparum malaria

\begin{tabular}{|c|c|c|c|c|c|c|}
\hline Variables & Number enrolled & $\begin{array}{l}P C \\
>2 d\end{array}$ & $\begin{array}{l}\text { Crude OR } \\
(95 \% \mathrm{Cl})\end{array}$ & $\begin{array}{l}P \\
\text { Value }\end{array}$ & Adjusted OR (95\% Cl) & $\begin{array}{l}P \\
\text { Value }\end{array}$ \\
\hline \multicolumn{7}{|c|}{ Axillary temperature $\left({ }^{\circ} \mathrm{C}\right)$} \\
\hline$<38.0$ & 2326 & 1012 & 1 & & 1 & \\
\hline$\geq 38.0$ & 228 & 139 & $2.02(1.53-2.67)$ & $<0.0001$ & $1.80(1.30-2.50)$ & $<0.001$ \\
\hline \multicolumn{7}{|c|}{ Parasitaemia (/ $\mu$ l blood) } \\
\hline$\leq 20,000$ & 1328 & 463 & 1 & & 1 & \\
\hline$>20,000$ & 683 & 467 & $5.25(4.20-6.48)$ & $<0.0001$ & $5.13(4.14-6.35)$ & $<0.001$ \\
\hline \multicolumn{7}{|c|}{ Drug treatment * } \\
\hline CQ & 388 & 275 & 1 & 1 & 1 & \\
\hline$A Q$ & 573 & 298 & $0.44(0.33-0.58)$ & $<0.0001$ & $0.79(0.63-0.98)$ & $<0.03$ \\
\hline AQAS & 142 & 14 & $0.05(0.03-0.08)$ & $<0.0001$ & $0.24(0.10-0.57)$ & $<0.0001$ \\
\hline AQPS & 69 & 26 & $0.24(0.14-0.42)$ & $<0.0001$ & $0.44(0.26-0.73)$ & 0.002 \\
\hline AQSP & 91 & 34 & $0.25(0.15-0.39)$ & $<0.0001$ & $0.43(0.29-0.68)$ & $<0.0001$ \\
\hline AMQ & 174 & 10 & $0.03(0.01-0.05)$ & $<0.0001$ & $0.04(0.02-0.09)$ & $<0.0001$ \\
\hline$A L$ & 90 & 6 & $0.03(0.01-0.07)$ & $<0.0001$ & $0.05(0.02-0.12)$ & $<0.0001$ \\
\hline AS & 120 & 3 & $0.01(0.00-0.03)$ & $<0.0001$ & $0.02(0.00-0.06)$ & $<0.0001$ \\
\hline COT & 104 & 61 & $0.58(0.37-0.91)$ & 0.017 & $1.03(0.68-1.36)$ & 0.877 \\
\hline CQCP & 315 & 189 & $0.61(0.45-0.84)$ & 0.002 & $1.09(0.83-1.42)$ & 0.512 \\
\hline CQKET & 70 & 36 & $0.43(0.25-0.73)$ & 0.001 & $0.77(0.47-1.25)$ & 0.029 \\
\hline CQPS & 107 & 46 & $0.31(0.19-0.48)$ & $<0.0001$ & $0.54(0.36-0.82)$ & 0.004 \\
\hline MQ & 176 & 40 & $0.12(0.08-0.18)$ & $<0.0001$ & $0.21(0.15-0.31)$ & $<0.0001$ \\
\hline SP & 291 & 186 & $0.72(0.52-1.00)$ & 0.055 & - & - \\
\hline SPP & 42 & 13 & $0.18(0.09-0.37)$ & $<0.0001$ & $0.33(0.17-0.98)$ & 0.001 \\
\hline
\end{tabular}

$\mathrm{Cl}$, confidence interval; $\mathrm{OR}$, odd ratio; $\mathrm{PC}$, parasite clearance

* Values of OR represent chances of delay in parasite clearance

two weeks of commencing therapy was related to parasite clearance time; it rose from $13 \%(188 / 1,374)$ among children who cleared their parasitaemia on day 1 or on day 2 to $24.5 \%(245 / 1,000)$ among those who cleared their parasitaemia on day 3 or on day $4\left(\chi^{2}=44.69\right.$, $\mathrm{P}<0.0001$ ) (Figure 4).

\section{Pfmdr 1 and pfcrt findings}

A total of 260 isolates from 260 children were selected for genetic analysis of $p f m d r 1 / p f c r t$ of which 256 were successfully determined. None of the 260 children was aged $\leq 2$ years, but 137 children were aged 3 to $<5$ years. Infections were classified as mutant for $p f m d r 1 /$ pfcrt, mixed, or wild type. The prevalence of the three categories were $51 \%$ (70/139), 36\% (51/139) and 13\% (15/139), respectively in 2000 . In 2006 , the corresponding prevalence was 50\% (59/118), 36\% (42/118) and $14 \%$ (17/118). In the 256 children, 13\% (18/129), 4\% (4/93), and $5 \%(2 / 34)$ with mutant, mixed, and wild alleles, respectively were treatment failures. The difference between these proportions was significant $\left(\chi^{2}=6.49\right.$, df $=2, \mathrm{P}=0.039)$. The proportions of 3 to $<5$ year-olds with parasite clearance $>2 \mathrm{~d}$ in these groups were: $75 \%$ (48/64), 51\% (28/54) and 63\% (12/19), respectively for mutants, mixed and wild type. The difference in these proportions was significant $\left(\chi^{2}=6.84, \mathrm{df}=2\right.$, $\mathrm{P}=0.032$ ).

\section{Discussion}

The emergence of drug resistance in P. falciparum, in particular to CQ and SP, in south-western Nigeria has been relatively slow but steady $[12-14,25,26]$. The aetiology of the treatment failure in children from this endemic area has been multifactorial including the selection of $P f m d r-1$ gene following anti-malarial treatment $[7,10]$. The overall parasitological failure rate of over $40 \%$ with CQ and SP $[25,26]$ clearly warrants discontinuing the use of these drugs as monotherapies or their inclusion as part of combination therapies. Thus, the recommended continuing use of SP in intermittent preventive therapy in pregnancy in this endemic area [27] should have little or no impact because of widespread clinical and molecular markers of resistance to this drug [28]. The latter is supported by a recent study (Gbotosho \& Happi, personal communication), showing lack of protective value of SP in intermittent preventive therapy of malaria in a group of pregnant women in this endemic area. 


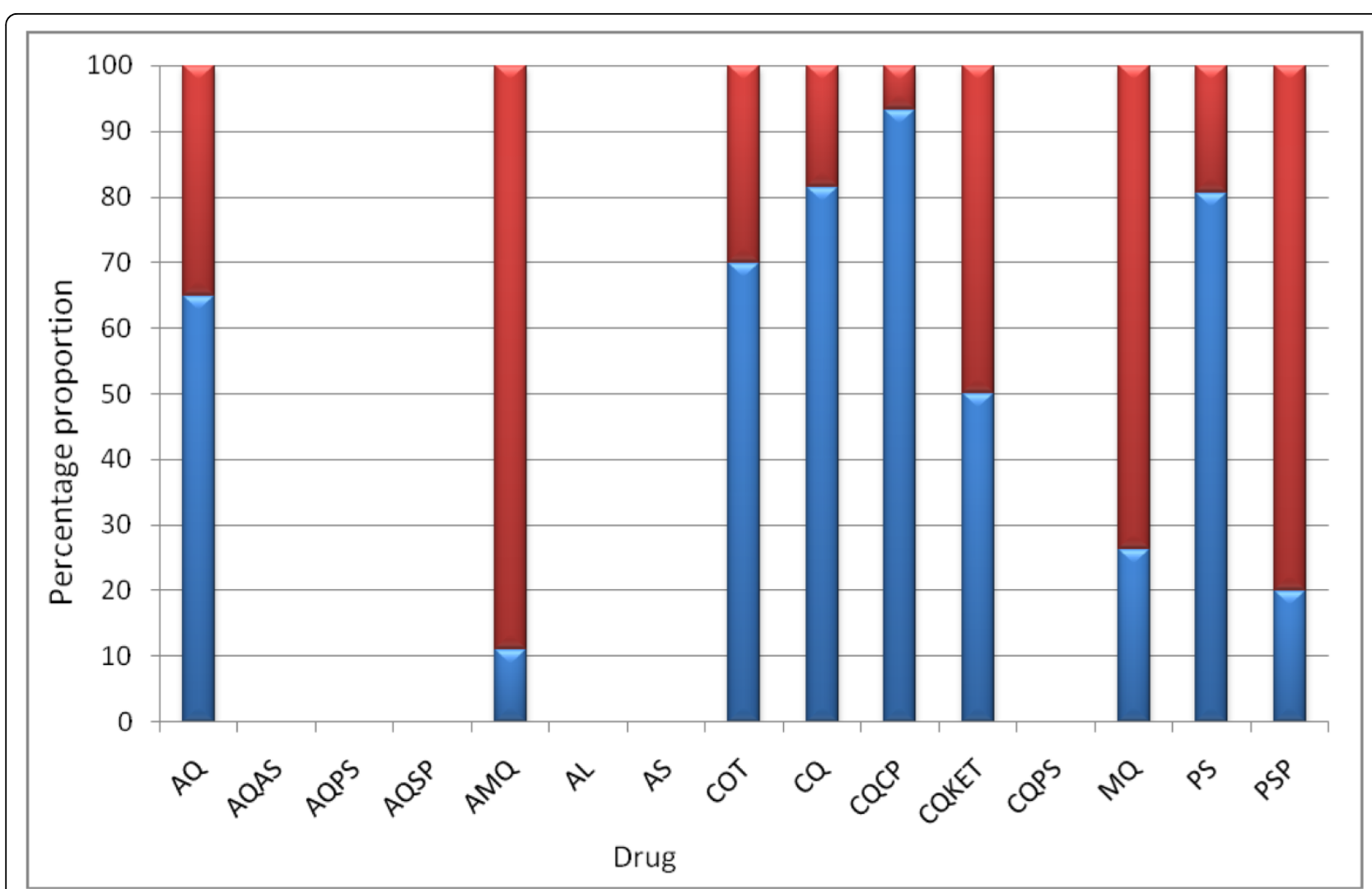

Figure 3 Treatment failures following antimalarial drugs in children. Total failure (Red triangle), children who previously had delay in parasite clearance (Blue triangle).

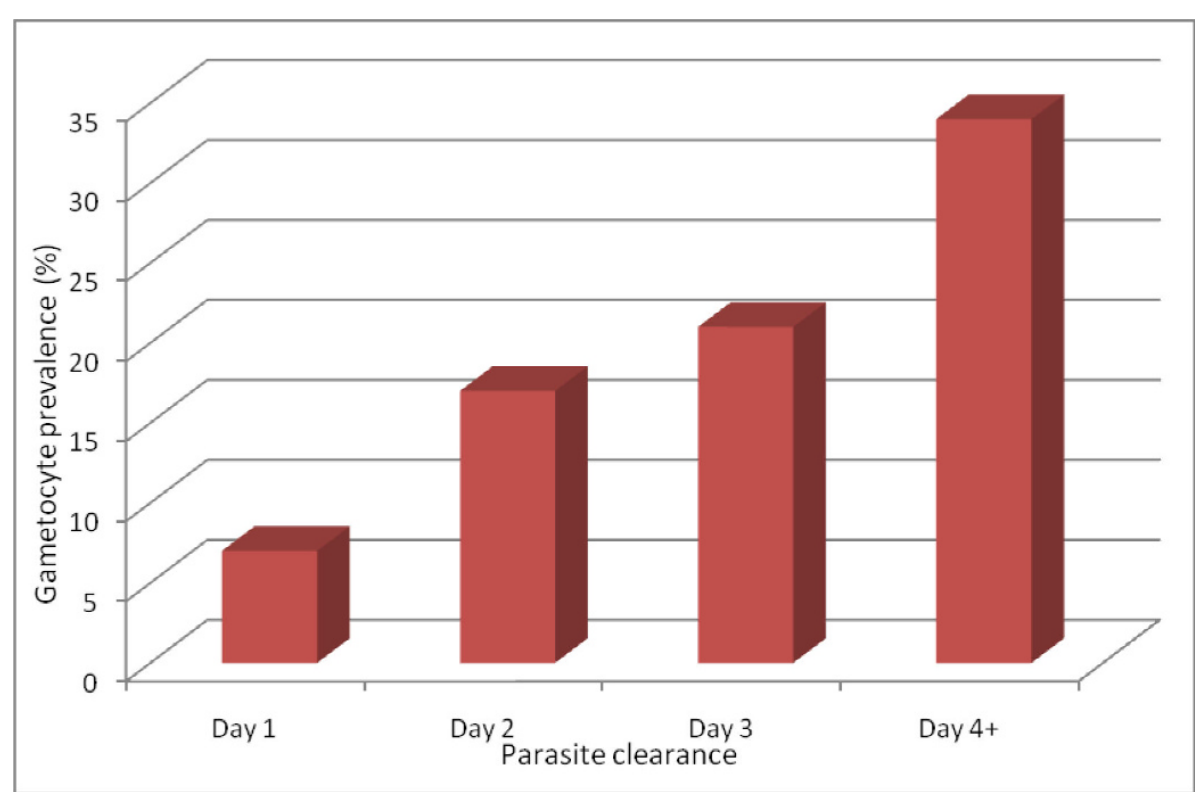

Figure 4 Relationship between parasite clearance and gametocyte carriage. 
Resistant infections at case management and community levels are difficult to manage and early identification and prompt treatment of patients at risk of subsequent treatment failure would improve patient care and community management of resistant infections. In the present study, a systematic evaluation of the pre-treatment and during-treatment factors contributing to delay in parasite clearance, the relationship between delay in parasite clearance and treatment failure, and effects of non-artemisinin and artemisinin mono- or combination therapy on parasite clearance in children were done. The results showed that delay in parasite clearance is multifactorial in origin with the host, parasite and drug factors contributing almost equally to delay in clearance and subsequent failure of treatment in those with delay in parasite clearance.

The age-and pretreatment parasite population sizedependent delay in parasite clearance are likely linked to treatment outcome by affecting both the immunedependent ability to clear and the probability of survival of a subpopulation of asexual blood parasite stages, respectively. In cases of polyclonal infections, a common finding in this endemic area $[7,29,30]$, this subpopulation may likely comprise drug-insensitive parasites $[22,31,32]$. Thus, these two phenomena are reminiscent of the age- and parasite density-dependent risks of treatment failure for many anti-malarial drugs $[3,5,25,26,33,34]$. Therefore, it would appear delay in parasite clearance is an intermediate step in the progression from drug-sensitive to drug insensitive outcome for many anti-malarials. This should be so because in uncomplicated malaria infections, there is less inhibition of parasite multiplication by unbound anti-malarial drug levels as resistance increases [31].

Interestingly, pre-treatment and intra-treatment elevated body temperatures were independent risk factors for delay in clearance. Fever is considered a crude measure of unspecific immune responsiveness [35]. If the findings are not due to chance, the presence of elevated body temperature a day after treatment began, coupled with a high parasite density should be sensitive clinical indicators of delay in response to anti-malarial drugs. Indeed, high parasite density on day 1 is a very sensitive indicator of delay in parasite clearance (Table 4). Again, these are reminiscent of the indicators of the risk factors for treatment failure for many anti-malarial drugs.

In general, progressive and significant elongations in parasite clearance times over time were striking features of treatment outcomes in children treated with $\mathrm{CQ}$, and $\mathrm{SP}$, the two most widely and longest used drugs in south-western Nigeria, and for $\mathrm{AQ}$, a drug that is less frequently used, but is a partner drug for artesunate. These elongations were not accompanied by significant increases in proportions of patients with delay in parasite clearance during the same periods in those treated with $C Q$ and $A Q$, suggesting similar mechanism(s) for development of resistance in the parasite to both drugs. In addition, the absence of increase in proportion with delay in clearance over time could have been due to the fact that these proportions were already above $50 \%$ when the studies began in 1996 and 2000, respectively for CQ and AQ. This would suggest that the $50 \%$ threshold may be the time to consider change in treatment policy at the community or national level in this endemic area.

Non-artemisinin monotherapy and non-artemisinin combination therapy were associated with significantly increased proportions of children with delay in clearance. These findings call for a new strategy to determine the maximum point in time at which to effect change in therapy in policy formulation with the widespread use of ACT in Africa. Perhaps this time point may be when $50 \%$ of a population of under-three to under-five year olds show delay in parasite clearance. This is best exemplified by the results from the children treated with amodiaquine, where over $50 \%$ showed a delay in clearance and $65 \%$ of those who were treatment failures were those with demonstrable delay in clearance. These findings contrast sharply with those found in children treated with artesunate and artemisinin-based combination therapy and strongly support the WHO recommendation of ACT [1] as first line treatment globally. However, it is likely that with increasing use of ACT on the African continent, significant increases in the proportion of children with delay in parasite clearance will be seen within a decade as has recently been demonstrated for artesunate-mefloquine use in north-western Thailand [36].

Delay in parasite clearance was associated with increased gametocyte carriage and, therefore, presumably with a potential for increased transmissibility of drug resistant phenotype. This is of public health import since delay in parasite clearance, by virtually all antimalarial drugs, including ACT, is associated with an increased risk of gametocytaemia [36-38].

Over the study period the prevalence of $p f m d r 1 / p f c r t$ mutants and mixed mutants/wild was above $50 \%$, and with little or no increase between 2000 and 2006. Intriguingly, this was associated with increase in parasite clearance time in CQ and AQ-treated patients. Carriage of mutant parasites was associated with an increased risk of treatment failure. Additionally, the proportions of under five-year-olds with delay in parasite clearance increased with genotype classification suggesting that delay in parasite clearance was associated with drug resistance and treatment failure in young children. However, there are other factors that may affect susceptibility that were not evaluated in these children. 
There is need to justify the definition of delay in clearance used in this study: one asexual cycle of the blood stage infection takes approximately $48 \mathrm{~h}$. Thus after two days, the parasites appearing in blood and visible by microscopy when the patient presents, should be the one to appear in blood $48 \mathrm{~h}$ after treatment began if the drug does not kill all the parasites [31]. Thus the use of delay in clearance, in the opposite, and in a more practical way, is analogous to the parasite reduction ratio [22], but with an inclination for easy applicability and operational research.

\section{Conclusion}

A better understanding of the multifactorial causes and mechanisms of delay in parasite clearance following anti-malarial treatment regimens can provide vital information for setting policy recommendations at case management, community, and national levels and prolonging the clinical life of the currently useful anti-malarials.

\section{Conflict of interests}

The authors declare that they have no competing interests.

\begin{abstract}
Acknowledgements
We thank the patients and their parents for participating in the studies over the years. We are grateful to our colleagues and assistants who participated in the data collection. The studies received financial support from the UNDP/World Bank/WHO Special Programme for Research and Training in Tropical Diseases, The Nigerian Federal Ministry of Health, Ipca

Pharmaceuticals, and Pfizer Global Pharmaceuticals. AS was supported by a WHO/TDR Career Development Award, and Ipca Pharmaceuticals and Pfizer Global Pharmaceuticals Grants. CTH is supported by a Fogarty International Research Collaboration Award (FIRCA) no. NIH RO3TW007757-02, the IAEA project RAF/0625, the UNICEF/UNDP/World Bank/WHO/TDR/PAG/SouthSouth Initiative project ID A50337, the Harvard Malaria Initiative and EDCTP Grant Award no. TA2007/.40200016 for Senior Research Fellowship. GOG is supported by the MIM/TDR project ID A20239.
\end{abstract}

\section{Author details}

'Department of Pharmacology \& Therapeutics, University of Ibadan, Ibadan, Nigeria. ${ }^{2}$ Malaria Research Laboratories, Institute for Medical Research and Training, University of Ibadan, Ibadan, Nigeria. ${ }^{3}$ Department of Physiology, University of Ibadan, Ibadan, Nigeria.

\section{Authors' contributions}

AS led the design, conduct, data analysis and manuscript preparation. EOA was involved in manuscript preparation. GOG and CTH were involved in design, conduct, and preparation of the manuscript. AS was involved with data analysis. OAF, TMO and OSM were involved with conduct of study. All authors read and approved the manuscript.

Received: 26 August 2009

Accepted: 15 February 2010 Published: 15 February 2010

\section{References}

1. World Health Organization: The use of antimalarial drugs. Report of a WHO Informal Consultation. Document WHO/CDS/RBM/2001.33 WHO, Geneva 2001.

2. Wang P, Lee CS, Bayoumi R, Djimde A, Doumbo O, Swedberg G, Dao LD, Mshinda H, Tanner M, Watkins WM, Sims PGF, Hyde JE: Resistance to antifolates in Plasmodium falciparum monitored by sequence analysis of dihydropteroate synthetase and dihydrofolate reductase alleles in a large number of field samples of diverse origin. Mol Biochem Parasitol 1997, 89:161-177.

3. Fontanet AL, Walker AM: Predictors of treatment failure in multiple drug resistant falciparum malaria: results from a 42-day follow-up of 224 patients in eastern Thailand. Am J Trop Med Hyg 1993, 49:465-472.

4. Nosten F, Luxemburger C, ter Kuile FO, Woodrow C, Pa Eh J, Chongsuphajaisidhhi T, White NJ: Three day artesunate-mefloquine combination for the treatment of multidrug-resistant falciparum malaria. $J$ Inf Dis 1994, 170:971-977.

5. ter Kuile FO, Luxemburger C, Nosten F, Thwai KL, Chongsuphajaisidhhi T, White NJ: Predictors of mefloquine treatment failure: a prospective study of 1590 patients with uncomplicated malaria. Trans R Soc Trop Med Hyg 1995, 89:660-664.

6. Wongsrichanalai $C$, Meshnick SR: Declining artesunate-mefloquine efficacy against falciparum malaria on the Cambodia-Thailand border. Emerg Infect Dis 2008, 14:716-719.

7. Happi CT, Gbotosho GO, Folarin OA, Bolaji OM, Sowunmi A, Kyle DE, Milhous W, Wirth DF, Oduola AMJ: Association between mutations in Plasmodium falciparum chloroquine resistance transporter and $P$. falciparum multidrug resistance 1 genes and in vivo amodiaquine resistance in $P$. falciparum malaria-infected children in Nigeria. Am J Trop Med Hyg 2006, 75:155-161.

8. Holmgren G, Gil JP, Ferreira PM, Veiga Ml, Obonyo CO, Björkman A: Amodiaquine resistant Plasmodium falciparum malaria in vivo is associated with selection of pfcrt $76 \mathrm{~T}$ and pfmdr 1 86Y. Infect Genet Evol 2006, 6:309-314.

9. Borrmann S, Matsiegui P-B, Missinou MA, Kremner PG: Effects of Plasmodium falciparum parasite population size and patient age on early and late parasitological outcomes of antimalarial treatment in children. Antimicrob Agents Chemother 2008, 52:1799-1805.

10. Happi CT, Gbotosho GO, Folarin OA, Sowunmi A, Hudson T, O' Neil M, Milhous W, Wirth DF, Oduola AMJ: Selection of Plasmodium falciparum multi-drug resistance gene 1 alleles in asexual stages and gametocytes by artemether-lumefantrine in Nigerian children with uncomplicated falciparum malaria. Antimicrob Agents Chemother 2009, 53:888-895.

11. Salako LA, Ajayi FO, Sowunmi A, Walker O: Malaria in Nigeria: a revisit. Ann Trop Med Parasitol 1990, 84:435-445.

12. Sowunmi A, Oduola AMJ, Ogundahunsi OAT, Salako LA: Comparative efficacy of chloroquine plus chlorpheniramine and pyrimethaminesulphadoxine in acute uncomplicated falciparum malaria in Nigerian children. Trans R Soc Trop Med Hyg 1998, 92:77-81.

13. Sowunmi A, Oduola AMJ, Ogundahunsi OAT, Salako LA: Enhancement of the antimalarial effect of chloroquine by chlorpheniramine in vivo. Trop Med Int Health 1998, 3:177-183.

14. Sowunmi A: A randomized comparison of chloroquine, amodiaquine and their combination with pyrimethamine-sulfadoxine in the treatment of acute, uncomplicated, Plasmodium falciparum malaria in children. Ann Trop Med Parasitol 2002, 96:227-238.

15. Sowunmi A: A randomized comparison of chloroquine and chloroqunie plus ketotifen, in the treatment of acute, uncomplicated, Plasmodium falciparum malaria in children. Ann Trop Med Parasitol 2003, 97:103-117.

16. Sowunmi A, Gbotosho GO, Happi $C$, Adedeji AA, Fehintola FA, Folarin OA, Tambo E, Fateye BA: Therapeutic efficacy and effects of artemetherlumefantrine and amodiaquine-sulfalene-pyrimethamine on gametocyte carriage in children with uncomplicated Plasmodium falciparum malaria in southwestern Nigeria. Am J Trop Med Hyg 2007, 77:235-241.

17. World Health Organization: Severe falciparum malaria. Trans $R$ Soc Trop Med Hyg 2000, 94(Suppl 1):1-90.

18. Shaper $A G$, Lewis $P$ : Genetic neutropenia in people of African origin. Lancet 1971, ii:1021-1023.

19. Ezeilo GC: Neutropenia in Africans. Trop Geogr Med 1971, 23:264-267.

20. Sowunmi A, Akindele JA, Balogun MA: counts in falciparum malaria in African children from an endemic area. Afr J Med Med Sci 1995, 24:145-149.

21. World Health Organization: Chemotherapy of malaria and resistance to antimalarials. Technical Report Series No. 529 WHO, Geneva 1973.

22. White NJ: Assessment of the pharmacodynamic properties of antimalarial drugs in vivo. Antimicrob Agents Chemother 1997, 41:1413-1422. 
23. Anonymous: Epi Info Version 6. A Word Processing Data Base and Statistics Program for Public Health on IBM-compatible Microcomputers Centers for Disease Control and Prevention, Atlanta, GA 1994.

24. Anonymous: SPSS for Windows Release 10.01 (Standard Version) SPSS Inc, Chicago, IL 1999.

25. Sowunmi A, Fateye BA, Adedeji AA, Fehintola FA, Gbotosho GO, Happi TC, Tambo E, Oduola AMJ: Predictors of the failure of treatment with chloroquine in children with acute, uncomplicated Plasmodium falciparum malaria, in an area with high and increasing incidences of chloroquine resistance. Trans R Soc Trop Med Hyg 2005, 99:535-544.

26. Sowunmi A, Fateye BA, Adedeji AA, Gbotosho GO, Happi TC, Bamgboye AE, Bolaji OM, Oduola AMJ: Predictors of the failure of treatment with pyrimethamine-sulfadoxine in children with uncomplicated, falciparum malaria. Acta Trop 2006, 98:6-14.

27. Federal Ministry of Health: National Antimalarial Drug Treatment Policy Abuja, Nigeria 2004.

28. Happi CT, Gbotosho GO, Folarin OA, Akinboye DO, Yusuf BO, Ebong OO, Sowunmi A, Kyle DE, Milhous W, Wirth DF, Oduola AMJ: Polymorphism in Plasmodium falciparum dhfr and dhps genes and age related in vivo sulfadoxine pyrimethamine resistance in malaria-infected patients from Nigeria. Acta Trop 2005, 95:183-193.

29. Happi TC, Thomas SM, Gbotosho GO, Falade CO, Akinboye DO, Gerena L, Hudson T, Sowunmi A, Kyle DE, Milhous W, Wirth DF, Oduola AMJ: Point mutations in the pfcrt and pfmdr-1 genes of Plasmodium falciparum and clinical response to chloroquine, among malaria patients from Nigeria. Ann Trop Med Parasitol 2003, 97:439-451.

30. Happi CT, Gbotosho GO, Sowunmi A, Falade CO, Akinboye DO, Gerena L, Kyle DE, Milhous W, Wirth DF, Oduola AMJ: Molecular analysis of Plasmodium falciparum recrudescent malaria infections in children treated with chloroquine in Nigeria. Am J Trop Med Hyg 2004, 70:20-26.

31. White NJ: Antimalarial drug resistance. J Clin Invest 2004, 113:1084-1092.

32. Nzila AM, Nduati E, Mberu EK, Sibley CH, Monks SA, Winstanley PA, Watkins MM: Molecular evidence of greater selective pressure for drug resistance exerted by the long acting antifolate pyrimethamine/ sulfadoxine compared with the short-acting chlorproguanil/dapsone on Kenyan Plasmodium falciparum. J Inf Dis 2000, 181:2023-2028.

33. Hamer DH, Macleod WB, Addo-Yobo E, Duggan CP, Estrella B, Fawzi WW, Konde-Lule JK, Mwakanasale V, Premji ZO, Sempertegui F, Ssengooba FP, Yeboah-Antwi K, Simon JL: Age, temperature, and parasitaemia predict chloroquine treatment failure and anaemia in children with uncomplicated Plasmodium falciparum malaria. Trans $R$ Soc Trop Med Hyg 2003, 97:422-428.

34. Dorsey G, Gasasira AF, Machekano R, Kamya MR, Staedke SG, Hubbard A: The impact of age, temperature, and parasite density on treatment outcomes from antimalarial clinical trials in Kampala, Uganda. Am J Trop Med Hyg 2004, 71:531-536.

35. Kwiatowski D, Nowak M: Periodic and chaotic host-parasite interactions in human malaria. Proc Natl Acad Sci USA 1991, 88:5111-5113.

36. Carrara VI, Zwang J, Ashley EA, Price RN, Stepniewska K, Barends M, Brockman A, Anderson T, McGready R, Phaiphun L, Proux S, van Vugt M, Hutagalung $R$, Lwin KM, Phyo AP, Preechapornkul P, Imwong M, Pukrittayakamee S, Singhasivanon P, White NJ, Nosten F: Changes in the treatment responses to artesunate-mefloquine on the northwestern border of Thailand during 13 years of continuous deployment. PLOS ONE 2009, 4:e4551.

37. Price $R$, Nosten $F$, Simpson JA, Luxemburger $C$, Paiphun $L$, ter Kuile $F$, van Vugt M, Chongsuphajaisiddhi T, White NJ: Risk factors for gametocyte carriage in uncomplicated falciparum malaria. Am J Trop Med Hyg 1999, 60:1019-1023.

38. Sowunmi A, Fateye BA, Adedeji AA, Fehintola FA, Happi TC: Risk factors for gametocyte carriage in uncomplicated falciparum malaria in children. Parasitol 2004, 129:255-262.

doi:10.1186/1475-2875-9-53

Cite this article as: Sowunmi et al:: Factors contributing to delay in parasite clearance in uncomplicated falciparum malaria in children. Malaria Journal 2010 9:53.

\section{Submit your next manuscript to BioMed Central and take full advantage of:}

- Convenient online submission

- Thorough peer review

- No space constraints or color figure charges

- Immediate publication on acceptance

- Inclusion in PubMed, CAS, Scopus and Google Scholar

- Research which is freely available for redistribution

Submit your manuscript at www.biomedcentral.com/submit
Biomed Central 